\author{
잣 부산물의 급여가 비육돈의 생산성, 혈액성상, 도체특성 및 분 \\ 내 유해가스 발생에 미치는 영향 \\ 이정호* 박광우* · 신승오** · 조진호** · 진영걸** · 김인호** \\ 국립수목원*, 단국대학교 동물자원학과**
}

\title{
Effects of Dietary Pine Cone Meal on Growth Performance, Blood Characteristics, Carcass Quality and Fecal Noxious Gases Compounds in Finishing Pigs
}

\author{
J. H. Lee*, K. W. Park*, S. O. Shin**, J. H. Cho**, Y. J. Chen** and I. H. Kim**
}

Korea National Arboretum*, Department of Animal Resource \& Science, Dankook University**

\begin{abstract}
This study was conducted to evaluate effects of dietary pine cone meal on growth performance, blood characteristics, carcass quality and fecal noxious gases compounds in finishing pigs. The total of sixty [(Landrace $\times$ Yorkshire $) \times$ Duroc $]$ pigs $(86.01 \pm 0.25 \mathrm{~kg}$ in average initial body weight $)$ were used in 35 days assay. Dietary treatments included 1) T1 (2\% cottonwood sawdust), 2$) \mathrm{T} 2(1 \%$ cottonwood sawdust $+1 \%$ pine cone meal) and 3) T3 (2\% pine cone meal). There were three dietary treatments with five replicate pens per treatment and four pigs per pen. During the overall periods, there were no significant differences in ADG (Average daily gain), ADFI (Average daily feed intake) and gain/feed ratio among treatments $(P>0.05)$. Also, Nutrient digestibilities and blood characteristics were not affected by dietary treatments. At the end of this experiment, $\mathrm{a}^{*}$-value of logissimus dorsi muscle color and sensory evaluation color were higher in $\mathrm{T} 3$ treatment than $\mathrm{T} 1$ treatment $(P<0.05)$. In fatty acid contents of lean, $\mathrm{C} 18: 1$ and total MUFA were significantly lower in $\mathrm{T} 1$ treatment than other treatments $(P<0.05)$. However, total $\omega 6$ and total PUFA were higher in $\mathrm{T} 1$ treatment than $\mathrm{T} 2$ treatment $(P<0.05)$. In fatty acid contents of fats, total SFA was significantly higher in $\mathrm{T} 2$ treatment than $\mathrm{T} 3$ treatment $(P<0.05)$. C18:1 was higher in $\mathrm{T} 2$ treatment than $\mathrm{T} 1$ treatment $(P<0.05)$. There were no significant differences in fecal noxious gas compounds among the treatments. In conclusion, the results of the experiment was affected by dietary supplementation of pine cone meal on meat color and fatty acid composition of pork in finishing pigs.
\end{abstract}

(Key words: Pine cone meal, Growth performance, Carcass characteristics, Fatty acid, Finishing pigs)

$$
\text { I. 서 론 }
$$

현재 축산업은 기업화 및 대규모화 되면서 이윤을 추구하는 단순경영에서 건강증진을 위 한 기능성과 유해물로부터의 안정성 및 환경오
염 발생 등 복합적인 기능을 요구하고 있다.

축산업에 있어서 생산비의 절감, 생산성, 육 질의 향상 및 분뇨에 의한 환경오염의 문제는 시급하고 중요한 당면 과제가 되었으며, 이를 해결하기 위한 방안으로 항생제 대체를 위한

Corresponding author : Dr. I. H. Kim, Dept. of Animal Resource \& Science, Dankook University \#29 Anseodong, Cheonan, Choongnam 330-714, Korea

Tel : 041-550-3652, Fax : 041-550-3604, E-mail : inhokim@dankook.ac.kr 
효모제, 효소제 및 생균제 등의 친환경 사료 첨가제 개발, 산업부산물의 이용, 약용식물의 첨가 등 여러 방면의 연구들이 활발하게 진행 되고 있다(Alder와 Damassa, 1980; Barrow, 1992; 곽 등, 2003; 권 등, 2003; 권 등, 2005).

최근 산업부산물은 생산량이 점차 늘어나는 실정이다. 곽 등(2003)은 저비용의 고품질 축산 물을 생산하기 위해 각종 부산물을 부존 사료 자원으로서, 재활용의 시도가 활발히 이루어지 고 있으며, 이러한 시도는 사료 자원의 확보차 원 뿐만 아니라 환경오염 감소 차원 등 다양한 측면에서 바람직하다고 보고하였다. 그러나, 산 업부산물의 수집, 처리 및 경제적인 이유로 활 용되지 못하는 어려움은 산업부산물을 활용하 는데 큰 걸림돌이 되고 있으며, 이러한 이유로 미처 이용되지 못하는 물량은 대부분 폐기되어 환경오염원으로 방치되고 있는 실정이다. 현 시점에서 산업부산물의 효율적인 사료화 연구 는 저가의 국내 부존사료 자원의 개발차원 뿐 만 아니라 환경오염원의 배출량을 줄이는 효과 를 얻을 수 있을 것으로 사료된다.

잣나무(Pinus koraiensis Sieb. et Zucc.)는 우리 나라 중부이북과 경남지역 등에서 널리 생장하 고 있으며, 만주동부, 시베리아 및 일본 일부에 까지 분포하고 있다(Critchfield and Little, 1966). 잣은 지방질 함량이 높고, 잣에 함유된 지방은 linoleic acid (48.6\%), oleic acid(22.8\%), arachidonic acid (14.4\%), palmitic acid (5.7\%), stearic acid $(1.84 \%)$, linolenic $\operatorname{acid}(0.7 \%)$ 등의 불포화 지방 산으로 이루어져 있으며 (김 등, 1984), 고 칼로 리 식품으로 알려져 있다. 2004 및 2005년의 농림부 통계에 의하면 각각 3,063 톤 및 2,680 톤의 잣이 국내에서 생산되었고, 2 3년 주기로 해걸이 결실이 발생하는 경우를 감안하여 보면 연간 2 천톤 이상의 잣이 생산되고 있다(농림 부, 2005; 농림부, 2006). 국내에서 잣 부산물은 연간 상당량이 생산되고 있으나, 대부분이 활 용되지 못하고 환경오염원으로 방치되고 있다.

잣나무에서 생산되는 잎과 송이는 약리적 가 치가 높고, 일본에서는 항산화제로서의 기능이 있는 것으로 알려지고 있다(고 등, 2006). 잣나 무에는 영양물질 이외에 항균 (Cimanga 등,
2002), 살충효과 (Baricevic 등, 2001) 및 타감 작 용을 하는 약리적인 성분들이 함유되어 있으 며, 이러한 화학성분은 피부자극제, 소염제, 소 독제, 완화제 및 보향제로 이용되고 있다(임 등 2001; 양 등 2002). 잣나무 진에는 Terpenoid 계 성분, phenol계 성분, 타닌 및 알카로이드 성분이 함유되어 있으며 (홍 등, 2002), tepinolene 과 boreneol 성분은 담즙분비를 촉진하여 콜레 스테롤 수치를 낮추는 작용을 하는 것으로 알 려져 있다(김 등, 1986). 본 시험에서 사용된 잣 부산물은 잣과 송이의 정유물질을 추출한 후 남은 것으로 가축의 사료원료로 이용할 수 있는 생리활성 물질들이 함유되어 있어 양돈 사료의 사료 첨가제로서 활용가치가 높을 것으 로 사료된다.

따라서, 본 연구에서는 잣 부산물을 사료 첨 가제로 비육돈에 급여하여 생산성, 혈액성상, 도체특성 및 분내 악취 발생 물질에 미치는 영 향에 대해 알아보기 위하여 시험을 실시하였다.

\section{ㅍ. 재료 및 방법}

\section{1. 시험동물 및 시험설계}

3원 교잡종 $($ Landrace $\times$ Yorkshire $\times$ Duroc) 비 육돈 60 두를 공시하였고 시험 개시시의 평균 체중은 $86.01 \pm 0.25 \mathrm{~kg}$ 이었고 35 일간 돈방을 시험 단위로 하여 사양시험을 실시하였다.

시험설계는 1) T1 (2\% cottonwood sawdust), 2) $\mathrm{T} 2(1 \%$ cottonwood sawdust $+1 \%$ pine cone meal) 및 3) T3 (2\% pine cone meal)로 3 개 처 리를 하여 시험구당 5 돈방(4두/돈방)씩 공시돈 을 완전임의 배치하였다.

\section{2. 시험관리}

사양시험은 단국대학교 시험농장에서 실시하 였다. 시험사료는 NRC (1998) 요구량에 따라 배합한 옥수수-대두박 위주의 사료로서 3,441 $\mathrm{kcal} \mathrm{ME} / \mathrm{kg}, 16.30 \%$ crude protein, $0.93 \%$ lysine, $0.72 \%$ calcium 및 $0.55 \%$ phosphorus을 함유하였 다(Table 1). 시험 사료는 가루형태로 자유 채 
Table 1. Formula and chemical composition of the experiment diets

\begin{tabular}{|c|c|c|c|}
\hline Ingredient & $\mathrm{T}^{1)}$ & $\mathrm{T} 2^{1)}$ & $\mathrm{T} 3^{1)}$ \\
\hline Corn & 47.35 & 47.35 & 47.35 \\
\hline Wheat meal & 10.00 & 10.00 & 10.00 \\
\hline Soybean meal & 22.81 & 22.81 & 22.81 \\
\hline Cottonwood sawdust & 2.00 & 1.00 & - \\
\hline Pine cone meal & - & 1.00 & 2.00 \\
\hline Rapeseed meal & 1.20 & 1.20 & 1.20 \\
\hline Wheat bran & 3.00 & 3.00 & 3.00 \\
\hline Rice bran & 2.00 & 2.00 & 2.00 \\
\hline Tallow & 5.00 & 5.00 & 5.00 \\
\hline Molasses & 4.00 & 4.00 & 4.00 \\
\hline DCP & 1.00 & 1.00 & 1.00 \\
\hline Limestone & 0.86 & 0.86 & 0.86 \\
\hline L-Lysine $\cdot \mathrm{HCl}(98 \%)$ & 0.10 & 0.10 & 0.10 \\
\hline Vitamin/ mineral Premix ${ }^{2)}$ & 0.30 & 0.30 & 0.30 \\
\hline Salt & 0.30 & 0.30 & 0.30 \\
\hline Choline-50 (Liq.) & 0.03 & 0.03 & 0.03 \\
\hline $\begin{array}{l}\text { Antioxidant } \\
\text { (Ethoxyquin 25\%) }\end{array}$ & 0.05 & 0.05 & 0.05 \\
\hline \multicolumn{4}{|l|}{ Chemical composition $^{3)}$} \\
\hline $\mathrm{DE}, \mathrm{kcal} / \mathrm{kg}$ & 3,553 & 3,553 & 3,553 \\
\hline $\mathrm{ME}, \mathrm{kcal} / \mathrm{kg}$ & 3,441 & 3,441 & 3,441 \\
\hline Crude protein, \% & 16.30 & 16.30 & 16.30 \\
\hline Crude Fat & 7.95 & 7.95 & 7.95 \\
\hline Lysine, $\%$ & 0.93 & 0.93 & 0.93 \\
\hline Calcium, \% & 0.72 & 0.72 & 0.72 \\
\hline Phosphorus, \% & 0.55 & 0.55 & 0.55 \\
\hline
\end{tabular}

1) Abbreviated TI; added cottonwood sawdust 2\%, T2; added cottonwood sawdust $1 \%+$ pine cone meal $1 \%$ and $\mathrm{T} 3$; added pine cone meal $2 \%$.

2) Supplied per kg diet: vitamin $A, 10,000$ IU; vitamin $D_{3}$, 2,000 IU; vitamin E, $42 \mathrm{IU}$; vitamin $\mathrm{K}, 5 \mathrm{mg}$; riboflavin, 2,400mg; vitamin $\mathrm{B}_{2}, 9.6 \mathrm{mg}$; vitamin $\mathrm{B}_{6}, 2.45 \mathrm{mg}$; vitamin $\mathrm{B}_{12}, 40 \mu \mathrm{g}$; niacin, $49 \mathrm{mg}$; pantothenic acid, 27 $\mathrm{mg}$; biotin, $0.05 \mathrm{mg}$; $\mathrm{Cu}, 140 \mathrm{mg}$; Fe, $145 \mathrm{mg}$; Zn, $179 \mathrm{mg}$; $\mathrm{Mn}, 12.5 \mathrm{mg}$; I, 0.5mg; Co; $0.25 \mathrm{mg}$, Se, $0.4 \mathrm{mg}$.

3) Calculated values.
식토록 하였으며, 물은 자동급수기를 이용하여 자유로이 먹을 수 있도록 조절하였다.

\section{3. 잣 부산물의 제조 방법 및 조성}

잣 부산물은 8 월 중순부터 10 월에 수확한 것 으로 식용으로 사용하는 잣과 정유물질을 추출 하고 남은 잣껍질, 잣송이 및 잣 나뭇잎 등의 부산물을 실온에서 건조시킨 후 분말의 형태로 곱게 분쇄하였으며, 이때 건조 감량은 약 $9 \%$ 수준이었다. 본 시험에서 사용한 잣 부산물의 일반조성은 건물 함량이 $87 \%$, 조회분 함량이 $20.34 \%$ 및 $4882.10 \mathrm{~g} / \mathrm{cal}$ 의 에너지를 함유하였다.

\section{4. 조사항목}

(1) 일당증체량, 일당사료섭취량 및 사료효율 체중 및 사료 섭취량은 시험 개시시 및 종료 시에 각각 측정하여 일당증체량, 일당사료섭취 량 및 사료효율을 계산하였다.

(2) 영양소 소화율

영양소 소화율을 측정하기 위하여 시험 표시 물로 산화크롬 $0.2 \%$ 첨가한 시험사료를 시험 종료 전에 7일간 급여하여 시험 종료 전, 항문 마사지 법으로 분을 채취하였다. 채취한 분은 $60^{\circ} \mathrm{C}$ 의 건조기에 72 시간 건조 시킨 후 Willey mill로 분쇄 후 분석에 이용하였다. 사료의 일 반석분과 표시물로 혼합된 $\mathrm{Cr}$ 은 $\mathrm{AOAC}(1995)$ 에 제시된 방법에 의해 분석하였다.

\section{(3) 혈액성상}

혈액채취는 각 처리당 10 마리를 임의 선발하 여 개시 및 종료시에 각각 경정맥(Jugular)에서 $\mathrm{K}_{3}$ EDTA vacuum tube(Becton Dickinson Vacutainer Systems, Franklin Lakes, NJ)를 이용하여 혈액 $2 \mathrm{~mL}$ 채취하여 자동혈액분석기 (ADVID 120, Bayer, USA)를 이용하여 $\mathrm{WBC}, \mathrm{RBC}$ 및 Lymphocyte를 조사하였다. 또한 혈청 생화학 적 검사는 시험개시 및 종료시에 경정맥에서 Vacuum tube(Becton Dickinson Vacutainer Systems, Franklin Lakes, NJ)를 이용하여 혈액을 $5 \mathrm{~mL}$ 
채취하여 $4^{\circ} \mathrm{C}$ 에서 $2,000 \times \mathrm{g}$ 로 30 분간 원심 분 리하여 혈청을 분석에 이용하였다. 분리된 혈 청은 enzymatic colorimetric method(Allain 등, 1974)에 의하여, 총 콜레스테롤 농도는 총 콜레 스테롤 검사 시약(Boehringer Mannheim, Germany) 에, $\mathrm{HDL}$ 콜레스테롤 농도는 HDL-C 검사 시약 (Boehringer Mannheim, Germany)을 이용하였다. TG (Triglyceride) 농도는 Triglyceride kit (Boehringer Mannheim, Germany)에 반응시켜 자동 생화 학 분석기 (HITACHI 747, Hitachi, Japan)를 이용 하여 측정하였다. $\mathrm{LDL}+\mathrm{VLDL}$ 콜레스테롤 농 도는 Naoyuki와 Yoshiharu(1995)의 방법에 따라 측정하였다.

\section{(4) 도체특성}

도체특성 분석에 사용된 돈육은 도살 후 $4{ }^{\circ} \mathrm{C}$ 냉장고에 24시간 저장 후, 각 처리구별로 10 두 씩을 선별하여 반도체 등심 부위 (M. longissimus dorsi)를 분할 정형하여 분석에 이용하였다. 육 색은 Chromameter (Model CR 210, Minolta Co., Japan)를 사용하여 각 sample 당 5회 반복하여 측정하였으며, 이때 표준색판은 $\mathrm{L}^{*}=89.2, \mathrm{a}^{*}=$ $0.921, \mathrm{~b}^{*}=0.783$ 으로 하였다. 육안검사는 5 명의 관능검사요원을 구성하여 수행하였으며, NPPC 기준안에 의해 신선육의 육색 (color:1 5), 근내 지방도 (marbling:1 5), 경도 (firmness:1 5)를 조 사하였다. $\mathrm{pH}$ 는 도축 24시간 후에 5 번째와 6 번 째 늑골 사이의 등심부위를 채취하여 $\mathrm{pH}$ meter (77P, Istek, Korea)를 이용하여 측정하였다. 등 심단면적은 구적기 (MT-10S, MT precision, Japan)를 이용하여 등심단면적을 측정하였고, 육즙삼출율 (drip loss)은 시료를 $2 \mathrm{~cm}$ 두께의 일 정한 모양으로 절단한 후 polyethylene bag에 넣 어 $4^{\circ} \mathrm{C}$ 에서 7 일간 보관하면서 발생되는 감량을 측정하여 계산하였다. 가열감량 (cooking loss)은 시료를 일정한 모양으로 절단하여 무게를 측정 후, polyethylene bag에 넣고 $75^{\circ} \mathrm{C}$ 항온 수조에 서 30 분간 가열하고 상온에서 30 분간 방냉 시 킨 후 시료의 무게를 측정하여 가열감량을 측 정하였다.

가열감량 $=$ $\frac{\text { 가열전 시료의 무게-가열후 시료의 무게 }}{\text { 가열전 시료의 무게 }} \times 100$

보수력 (Water holding capacity)은 Hofmann 등 (1982)의 방법으로 전체면적과 육의 면적의 비율을 기록하여 측정하였으며, 지방산패도 (TBARS) 분석은 Witte 등 (1970)에 의한 Thiobarbituric acid(TBA)가 측정법을 이용하여 분석하 였다. 등지방 두께 측정은 digital backfat indicator (Reno lean-meter ${ }^{\circledR}$, USA)를 이용하여 시 험 종료시 마지막 늑골 (갈비뼈) 부위에서 추정 하였다.

\section{(5) 지방산 분석}

지방 추출은 Folch 등(1957)의 방법으로 chloroform과 methanol로 추출하였다. 시료 $10 \mathrm{~g}$ 을 시료의 5 10배 folch용액(chloroform: methanol $=2: 1$ )에 2 시간 추출한 후 분별깔대기에 filtering 하여 담고 $0.8 \% \mathrm{KCl}$ 을 첨가하여 5 분간 혼합한 후, $3,000 \mathrm{rpm}$ 에서 10 분간 원심분리 시켰다. 하 층은 funnel filter paper에 sodium anhydrous sulfate를 첨가하고 filtering 하여 분리한 후 45 ${ }^{\circ} \mathrm{C}$ 에서 진공 농축기로 농축하여 추출하였다. 추출한 지방은 $\mathrm{NaOH} / 0.5 \mathrm{~N}$ methanol $10 \mathrm{~mL}$ 에 넣고 $80 \sim 90^{\circ} \mathrm{C}$ 에서 6 분간 반응, $14 \% \mathrm{BF}_{3} 5 \mathrm{~mL}$ 를 넣고 3 분간 반응시키고, 핵산 $10 \mathrm{~mL}$ 를 넣고 1 분간 반응시켜 냉각시킨 후 포화 $\mathrm{NaCl}$ 을 넣어 반응을 종결시킨 후 $\mathrm{GC} / \mathrm{FID}$ 로 분석하였다.

(6) 분내 유해가스 발생물질 분석

분내 암모니아 $\left(\mathrm{NH}_{3}\right)$, 휘발성 지방산 및 황화 수소 $\left(\mathrm{H}_{2} \mathrm{~S}\right)$ 발생량을 측정하기 위하여 시험 종 료시에 각 처리구에서 동일한 시간동안 배설된 분을 처리당 4마리로부터 채취한 후, 분석에 이용하였다. 암모니아, 휘발성 지방산 및 황화 수소의 측정은 시료 $300 \mathrm{~g}$ 을 취하여 $1000 \mathrm{~mL}$ 의 밀봉된 플라스틱 용기에 넣고 24시간 발효시킨 후, 1 일부터 30 일 동안 실온에 보관하면서 Gastec (Model GV-100, GASTEC, Japan)을 사용 하여 분내 유해가스 발생물질 $\left(\mathrm{NH}_{3}, \mathrm{H}_{2} \mathrm{~S}\right.$, Acetic acid)을 측정하였다. 


\section{5. 통계처리}

모든 자료는 SAS(1996)의 General Linear Model Procedure를 이용하여 분산분석을 실시하 였고, Ducan's multiple range test (Duncan, 1955) 로 처리하여 시험구 평균간 차이의 유의성 유 무 여부를 검정하였다.

\section{III. 결과 및 고찰}

\section{1. 생산성}

비육돈에 있어서 잣 부산물의 급여에 따른 일당증체량, 일당사료 섭취량 및 사료효율에 미치는 영향은 Table 2에 나타내었다. 전체 사 양 시험 기간 동안 종료시 체중, 일당증체량, 일당사료섭취량 및 사료효율은 처리구간에 유 의적인 차이가 없었다 $(P>0.05)$.

길(2007)은 잣송이 분말을 비육돈 및 육계에 급여시 일당증체량 및 사료효율이 감소하는 경 향을 나타내었으며, 잣송이 분말을 $2 \%$ 첨가 급 여한 처리구에서는 사료섭취량이 감소하였다고 보고하여 본 시험과 상이한 결과를 나타내었 다. 또한, 박 등(2005)은 잣 분말을 마우스에 급 여시 증체량에는 유의적 차이는 없었으나 사료 섭취량이 감소하였다고 보고하였으며, 최 등 (2007)은 육계에 침엽수 분말을 $3 \%$ 급여시 증 체량 및 사료섭취량이 감소한다고 보고하여 본
시험과 상이한 결과를 나타내었다.

본 시험의 결과 사료 내 잣 부산물의 첨가는 기호성 및 사료 이용성 증진에 영향을 미치지 않는 것으로 사료되며, 잣 부산물의 사료 첨가 제로서 가치평가 및 생산성에 관한 체계적인 연구가 이루어져야 할 것으로 사료된다.

\section{2. 영양소 소화율}

비육돈에 있어서 잣 부산물의 급여에 따른 영양소 소화율에 미치는 영향은 Table 3에 나 타내었다. 건물 소화율 및 질소 소화율에서는 처리구간에 유의적인 차이가 없었다 $(P>0.05)$.

최 등(2007)은 육계에 침엽수 부산물을 $3 \%$ 첨가 급여시 건물 소화율에 유의적인 차이가 나타나지 않았다고 보고하여 본 시험과 유사한 결과를 나타내었다.

본 시험의 결과 사료 내 잣 부산물의 첨가는 영양소 소화율에 영향을 미치지 않는 것으로 사료되며, 잣송이의 경우 세포벽의 구성 물질 들이 서로 조밀한 결합구조를 가지고 있기 때 문에 소화 흡수의 향상 효과가 나타나지 않은 것으로 사료된다.

\section{3. 혈액성상}

비육돈에 있어서 잣 부산물의 급여에 따른 혈액성상에 미치는 영향은 Table 4에 나타내었

Table 2. Effects of dietary pine cone meal on growth performance in finishing pigs

\begin{tabular}{lcccc}
\hline \multicolumn{1}{c}{ Items } & $\mathrm{T} 1^{1)}$ & $\mathrm{T}^{1)}$ & $\mathrm{T}^{1)}$ & $\mathrm{SE}^{2)}$ \\
\hline \hline $0 \sim 35$ days & & & & \\
Initial weight $(\mathrm{kg})$ & 86.30 & 85.81 & 85.92 & 0.20 \\
Final weight $(\mathrm{kg})$ & 115.00 & 116.47 & 116.58 & 1.07 \\
ADG $(\mathrm{kg})$ & 0.840 & 0.876 & 0.876 & 0.025 \\
ADFI (kg) & 2.754 & 2.764 & 2.718 & 0.087 \\
Gain/Feed & 0.298 & 0.317 & 0.322 & 0.019 \\
\hline
\end{tabular}

\footnotetext{
1) Abbreviated TI; added cottonwood sawdust $2 \%$, T2; added cottonwood sawdust $1 \%$ + pine cone meal $1 \%$ and T3; added pine cone meal $2 \%$

2) Pooled standard error.
} 
Table 3. Effects of dietary pine cone meal on nutrient digestibility in finishing pigs

\begin{tabular}{lcccc}
\hline \multicolumn{1}{c}{ Items (\%) } & $\mathrm{T} 1^{1)}$ & $\mathrm{T} 2^{1)}$ & $\mathrm{T}^{1)}$ & $\mathrm{SE}^{2)}$ \\
\hline \hline Dry matter & 76.85 & 77.55 & 76.78 & 1.65 \\
Nitrogen & 78.04 & 76.37 & 76.76 & 1.79 \\
\hline
\end{tabular}

1) Abbreviated TI; added cottonwood sawdust 2\%, T2; added cottonwood sawdust $1 \%+$ pine cone meal $1 \%$ and T3; added pine cone meal $2 \%$.

2) Pooled standard error.

Table 4. Effects of dietary pine cone meal on change of blood biochemical profiles in finishing pigs

\begin{tabular}{|c|c|c|c|c|}
\hline Items & $\mathrm{T} 1^{1)}$ & $\mathrm{T} 2^{1)}$ & $\mathrm{T}^{1)}$ & $\mathrm{SE}^{2)}$ \\
\hline \multicolumn{5}{|c|}{ Total cholesterol (mg/dL) } \\
\hline Initial & 89.40 & 87.40 & 92.60 & 3.48 \\
\hline Final & 87.60 & 88.60 & 90.40 & 3.75 \\
\hline Difference & -1.80 & 1.20 & -2.20 & 5.99 \\
\hline \multicolumn{5}{|c|}{ HDL cholesterol (mg/dL) } \\
\hline Initial & 32.20 & 27.00 & 31.80 & 2.44 \\
\hline Final & 29.40 & 33.20 & 27.80 & 1.68 \\
\hline Difference & -2.80 & 6.20 & -4.00 & 3.04 \\
\hline \multicolumn{5}{|c|}{ LDL cholesterol (mg/dL) } \\
\hline Initial & 46.60 & 49.40 & 48.80 & 3.57 \\
\hline Final & 44.80 & 41.40 & 47.40 & 1.68 \\
\hline Difference & -1.80 & -8.00 & 1.40 & 4.66 \\
\hline \multicolumn{5}{|c|}{ Triglyceride (mg/dL) } \\
\hline Initial & 39.00 & 31.40 & 33.80 & 2.57 \\
\hline Final & 42.00 & 43.20 & 45.20 & 3.82 \\
\hline Difference & -3.00 & -11.80 & -11.40 & 3.97 \\
\hline \multicolumn{5}{|l|}{$\mathrm{RBC}, \times 10^{6} / \mu \ell$} \\
\hline Initial & 6.42 & 6.36 & 6.60 & 0.24 \\
\hline Final & 6.58 & 6.74 & 6.12 & 0.26 \\
\hline Difference & 0.16 & 0.28 & -0.48 & 0.44 \\
\hline \multicolumn{5}{|l|}{$\overline{\mathrm{WBC}}, \times 10^{3} / \mu \ell$} \\
\hline Initial & 18.05 & 16.03 & 18.07 & 1.42 \\
\hline Final & $20.19^{\mathrm{b}}$ & $21.22^{\mathrm{ab}}$ & $26.03^{\mathrm{a}}$ & 1.45 \\
\hline Difference & 2.14 & 5.85 & 6.48 & 2.54 \\
\hline \multicolumn{5}{|c|}{ Lymphocyte (\%) } \\
\hline Initial & 73.00 & 76.25 & 67.80 & 4.04 \\
\hline Final & $65.60^{\mathrm{a}}$ & $69.00^{\mathrm{a}}$ & $52.33^{\mathrm{b}}$ & 3.60 \\
\hline Difference & -7.40 & -3.00 & -11.00 & 5.34 \\
\hline
\end{tabular}

1) Abbreviated TI; added cottonwood sawdust 2\%, T2; added cottonwood sawdust $1 \%+$ pine cone meal $1 \%$ and T3; added pine cone meal $2 \%$.

2) Pooled standard error.

a,b Means in the same row with different superscripts differ $(P<0.05)$. 
다. RBC, Total colesterol, HDL cholesterol, LDL cholesterol 및 Triglyceride의 함량 및 변화량에 서는 처리구간에 유의적인 차이가 없었다 $(P>0.05)$. 종료시 $\mathrm{WBC}$, Lymphocyte의 함량은 유의적인 차이가 있었으나 $(P<0.05)$ 변화량에 있어서는 유의적인 차이가 없었다 $(P>0.05)$.

길 (2007)은 비육돈 및 육계에 잣송이 부산물 급여 시 혈중 콜레스테롤 함량이 낮아졌다고 보고하여 본 시험과 상이한 결과를 나타내었 다. 박 등 (2005)은 잣 분말을 마우스에 5 20\% 첨가시 잣의 농도 증가에 따라 오히려 혈중 콜 레스테롤의 농도가 증가하는 경향이 나타났으 며, $\mathrm{HDL}$ 콜레스테롤는 감소하였고, $\mathrm{LDL}$, VLDL 콜레스테롤이 증가하였고, $1 \sim 5 \%$ 첨가한
시험에서는 혈중 콜레스테롤 함량, $\mathrm{HDL}, \mathrm{LDL}$, VLDL 콜레스테롤은 유의적인 차이가 나타나지 않았다고 보고하였다.

본 시험에서는 콜레스테롤 함량에 유의적인 차이가 나타나지 않았으며, 이러한 결과는 잣 의 생리활성 성분 중 콜레스테롤 수치를 감소 시키는 유효성분의 수준이 낮아 콜레스테롤 저 하에 미치는 영향이 미미했기 때문인 것으로 사료된다.

\section{4. 도체특성}

비육돈에 있어서 잣 부산물의 급여에 따른 도체특성에 미치는 영향은 Table 5에 나타내었

Table 5. Effects of dietary pine cone meal on meat quality in finishing pigs

\begin{tabular}{lcccc}
\hline Items & $\mathrm{T} 1^{1)}$ & $\mathrm{T} 2^{1)}$ & $\mathrm{T}^{1)}$ & $\mathrm{SE}^{2)}$ \\
\hline \hline Backfat thickness $(\mathrm{mm})$ & 17.07 & 16.90 & 17.52 & 1.24 \\
M. longissimus dorsi area $\left(\mathrm{cm}^{2}\right)$ & 38.49 & 39.06 & 39.16 & 0.32 \\
\hline Sensory evaluation & & & & \\
$\quad$ Color & $1.98^{\mathrm{b}}$ & $2.11^{\mathrm{ab}}$ & $2.36^{\mathrm{a}}$ & 0.09 \\
$\quad$ Marbling & 1.72 & 1.63 & 1.47 & 0.13 \\
Firmness & 1.88 & 1.87 & 1.70 & 0.10 \\
\hline Meat color & & & & \\
Lightness (L*) & 55.81 & 54.83 & 54.21 & 1.02 \\
Redness (a*) & $16.50^{\mathrm{b}}$ & $17.51^{\mathrm{ab}}$ & $18.15^{\mathrm{a}}$ & 0.36 \\
Yellowness (b*) & 7.31 & 7.52 & 7.58 & 0.25 \\
TBARS (mgMA/kg) & 0.032 & 0.031 & 0.029 & 0.004 \\
pH & 5.62 & 5.62 & 5.64 & 0.02 \\
Water holding capacity (\%) & 59.85 & 61.64 & 62.65 & 1.35 \\
\hline Drip loss (\%) & & & & 0.85 \\
2 days & 4.77 & 2.76 & 3.76 & 0.84 \\
4 days & 6.64 & 4.27 & 5.34 & 0.97 \\
6 days & 7.91 & 5.49 & 6.77 & 1.13 \\
Cooking loss (\%) & 31.71 & 32.51 & 0.85 \\
\hline
\end{tabular}

\footnotetext{
1) Abbreviated TI; added cottonwood sawdust 2\%, T2; added cottonwood sawdust $1 \%+$ pine cone meal 1\% and T3; added pine cone meal $2 \%$.

2) Pooled standard error.

${ }^{a, b}$ Means in the same row with different superscripts differ $(P<0.05)$.
} 
다. 육색에 있어서 적색도를 나타내는 $\mathrm{a}^{*}$-값은 $\mathrm{T} 3$ 처리구가 $\mathrm{T} 1$ 처리구와 비교하여 높게 나타 났으나 $(P<0.05)$, 명도를 나타내는 $\mathrm{L}^{*}$-값 및 황 색도를 나타내는 $b^{*}$-값은 처리구간에 유의적인 차이가 없었다 $(P>0.05)$. 육의 육색, 마블링 및 전단력에 대한 관능평가 결과 육색은 $\mathrm{T} 3$ 처리 구가 $\mathrm{T} 1$ 처리구와 비교하여 유의적으로 높게 나타났으나 $(P<0.05)$, 근내지방도 및 경도는 처 리구간에 유의적인 차이가 없었다 $(P>0.05)$. 육 의 육즙삼출율, $\mathrm{pH}$, 등심단면적, 조리감량, TBARS, 보수력 및 등지방두께는 전 처리구간 에 유의적인 차이가 없었다 $(P>0.05)$.

홍 등(2002)은 비육돈 사료 내 생약제 및 양 파 혼합 부산물을 첨가 급여한 시험에서 등지 방두께, 가열감량 및 드립감량에 있어서 유의
적인 차이가 나타나지 않았다고 보고하여 본 시험과 유사한 결과를 나타냈다. 또한, 길 (2007)은 비육돈에 잣송이 부산물 급여시 등지 방두께에 유의적인 차이가 없다고 보고하였으 며, 권 등(2005)은 비육돈에 약용식물을 첨가 급여시 등지방두께는 대조구와 유의적인 차이 가 없었다고 보고하여 본 시험의 결과와 유사 한 결과를 나타내었다. 안 등(2003)은 비육돈에 생리활성 물질이 함유된 쑥 분말 급여시 $\mathrm{pH}$ 및 TBARS가 낮게 나타났으며, 보수력을 향상 시킨다고 보고하였고, 주 등(1999)은 생리활성 물질이 함유된 양파부산물을 사료에 $3 \%$ 첨가 하여 육성돈에 급여시 TBARS가 낮게 나타났 다고 보고하여 본 시험과 상이한 결과를 나타 내었다.

Table 6. Effects of dietary pine cone meal on fatty acid composition of lean

\begin{tabular}{lcccc}
\hline \multicolumn{1}{c}{ Fatty acid (\%) } & \multicolumn{3}{c}{ Lean } \\
\cline { 2 - 4 } Myristic acid (C14:0) & $\mathrm{T} 1^{1)}$ & $\mathrm{T} 2^{1)}$ & $\mathrm{T} 3^{1)}$ & $\mathrm{SE}^{2)}$ \\
\hline \hline Palmitic acid (C16:0) & $1.28^{\mathrm{b}}$ & $1.50^{\mathrm{a}}$ & $1.41^{\mathrm{ab}}$ & 0.05 \\
Stearic acid (C18:0) & $22.28^{\mathrm{b}}$ & $24.07^{\mathrm{a}}$ & $23.14^{\mathrm{ab}}$ & 0.48 \\
Arachidic acid (C20:0) & 12.06 & 12.55 & 12.11 & 0.33 \\
Total SFA & $2.53^{\mathrm{a}}$ & $1.35^{\mathrm{b}}$ & $1.52^{\mathrm{b}}$ & 0.28 \\
Palmitoleic acid (C16:1) & 38.15 & 39.48 & 38.17 & 0.72 \\
Vaccenic acid (C18:1, trans-11) & 3.18 & 3.14 & 2.93 & 0.20 \\
Oleic acid (C18:1) & 0.44 & 0.43 & 0.51 & 0.09 \\
Total MUFA & $34.70^{\mathrm{b}}$ & $38.67^{\mathrm{a}}$ & $38.73^{\mathrm{a}}$ & 1.05 \\
Linoleic acid (C18:2) & $38.10^{\mathrm{b}}$ & $42.09^{\mathrm{a}}$ & $42.07^{\mathrm{a}}$ & 1.02 \\
$\gamma$ - Linolenic acid (C18:3) & $15.26^{\mathrm{a}}$ & $11.11^{\mathrm{b}}$ & $12.53^{\mathrm{ab}}$ & 0.87 \\
Total $\omega 6$ & 0.64 & 0.67 & 0.67 & 0.03 \\
a - Linolenic acid (C18:3) & $15.89^{\mathrm{a}}$ & $11.78^{\mathrm{b}}$ & $13.20^{\mathrm{ab}}$ & 0.86 \\
Total $\omega 3$ & 0.42 & 0.39 & 0.43 & 0.05 \\
Total PUFA & 0.42 & 0.39 & 0.43 & 0.05 \\
Total UFA & $16.31^{\mathrm{a}}$ & $12.17^{\mathrm{b}}$ & $13.63^{\mathrm{ab}}$ & 0.90 \\
Total UFA/SFA & 54.41 & 54.26 & 55.70 & 1.03 \\
\hline Abbra & 1.38 & 1.46 & 0.05 \\
\hline
\end{tabular}

\footnotetext{
1) Abbreviated TI; added cottonwood sawdust $2 \%$, T2; added cottonwood sawdust $1 \%+$ pine cone meal $1 \%$ and T3; added pine cone meal $2 \%$.

2) Pooled standard error.

a,b Means in the same row with different superscripts differ $(P<0.05)$.
} 
본 시험의 결과 잣 부산물의 급여는 적색도 에 영향을 미쳤으며, 천연 유래 각 생리활성 물질 급여에 따른 연구 결과들과의 차이는 각 생리활성 물질의 특성과 수준에 따라 생체 내 미치는 효과가 각각 다르게 나타났기 때문인 것으로 사료된다.

\section{5. 육의 지방산 조성}

비육돈에 있어서 잣 부산물의 급여에 따른 살코기 및 지방 내 돈육의 지방산 조성은
Table 6와 Table 7에 나타내었다. 살코기 내 지 방산 함량에서 Myristic acid 및 Palmitic acid는 $\mathrm{T} 2$ 처리구가 $\mathrm{T} 1$ 처리구와 비교하여 유의적으 로 높게 나타났으며 $(P<0.05)$, Arachidic acid는 $\mathrm{T} 1$ 처리구가 다른 처리구와 비교하여 가장 높 았다 $(P<0.05)$. Oleic acid 및 Total MUFA는 T1 처리구가 다른 처리구와 비교하여 가장 낮게 나타났으며 $(P<0.05)$, Linoleic acid, Total $\omega 6$ 및 Total PUFA는 T1 처리구가 $\mathrm{T} 2$ 처리구와 비교 하여 유의적으로 높았다 $(P<0.05)$. Total SFA, Total UFA 및 Total UFA/SFA는 처리구간에 유

Table 7. Effects of dietary pine cone meal on fatty acid composition of fat

\begin{tabular}{|c|c|c|c|c|}
\hline \multirow{2}{*}{ Fatty acid (\%) } & \multicolumn{4}{|c|}{ Fat } \\
\hline & $\mathrm{T} 1^{1)}$ & $\mathrm{T} 2^{1)}$ & $\mathrm{T}^{1)}$ & $\mathrm{SE}^{2)}$ \\
\hline Myristic acid (C14:0) & 1.62 & 1.60 & 1.49 & 0.05 \\
\hline Palmitic acid (C16:0) & 21.96 & 22.89 & 21.40 & 0.53 \\
\hline Stearic acid (C18:0) & 11.41 & 11.48 & 10.79 & 0.27 \\
\hline Total SFA & $34.99^{\mathrm{ab}}$ & $35.97^{\mathrm{a}}$ & $33.68^{b}$ & 0.66 \\
\hline Palmitoleic acid (C16:1) & 2.09 & 2.14 & 1.98 & 0.10 \\
\hline Elaidic acid (C18:1, trans-9) & 0.19 & 0.17 & 0.16 & 0.02 \\
\hline Vaccenic acid (C18:1, trans-11) & $0.47^{\mathrm{ab}}$ & $0.42^{\mathrm{b}}$ & $0.54^{\mathrm{a}}$ & 0.03 \\
\hline Oleic acid (C18:1) & $37.86^{\mathrm{b}}$ & $39.21^{\mathrm{a}}$ & $38.69^{\mathrm{ab}}$ & 0.36 \\
\hline Total MUFA & 40.61 & 41.90 & 41.37 & 0.42 \\
\hline Linoleic acid (C18:2) & 15.72 & 13.89 & 16.10 & 0.71 \\
\hline$\gamma$ - Linolenic acid (C18:3) & 0.03 & 0.04 & 0.03 & 0.01 \\
\hline Arachidonic acid (C20:4) & 0.25 & 0.24 & 0.24 & 0.01 \\
\hline Total $\omega 6$ & 15.99 & 14.15 & 16.36 & 0.71 \\
\hline a-Linolenic acid (C18:3) & 0.83 & 0.78 & 0.86 & 0.04 \\
\hline Docosahexaenoic acid (C22:6) & ND & 0.03 & 0.04 & 0.01 \\
\hline Total $\omega 3$ & 0.83 & 0.79 & 0.89 & 0.04 \\
\hline Total PUFA & 16.82 & 14.94 & 17.26 & 0.75 \\
\hline Total UFA & 57.43 & 56.85 & 58.62 & 0.61 \\
\hline Total UFA/SFA & 2.11 & 2.43 & 1.95 & 0.15 \\
\hline
\end{tabular}

\footnotetext{
1) Abbreviated TI; added cottonwood sawdust 2\%, T2; added cottonwood sawdust $1 \%+$ pine cone meal $1 \%$ and T3; added pine cone meal $2 \%$.

2) Pooled standard error.

a,b Means in the same row with different superscripts differ $(P<0.05)$.
} 
Table 8. Effects of dietary pine cone meal on fecal noxious gas compounds in finishing pigs

\begin{tabular}{lcccc}
\hline \multicolumn{1}{c}{ Items (ppm) } & $\mathrm{T}^{1)}$ & $\mathrm{T} 2^{1)}$ & $\mathrm{T}^{1)}$ & $\mathrm{SE}^{2)}$ \\
\hline \hline $\mathrm{NH}_{3}-\mathrm{N}$ & 7.25 & 7.75 & 7.25 & 3.66 \\
$\mathrm{H}_{2} \mathrm{~S}$ & 4.75 & 11.00 & 15.25 & 8.29 \\
Acetic acid & 0.25 & 0.38 & 1.13 & 0.47 \\
\hline
\end{tabular}

1) Abbreviated TI; added cottonwood sawdust 2\%, T2; added cottonwood sawdust $1 \%+$ pine cone meal $1 \%$ and T3; added pine cone meal $2 \%$.

2) Pooled standard error.

의적인 차이가 없었다 $(P>0.05)$. 지방 내 지방산 함량에서 total SFA는 $\mathrm{T} 2$ 처리구가 $\mathrm{T} 3$ 처리구 와 비교하여 유의적으로 높게 나타났으며 $(P<0.05)$, Palmitic acid 및 Stearic acid의 함량도 $\mathrm{T} 2$ 처리구가 $\mathrm{T} 3$ 처리구와 비교하여 높은 경향 을 나타내었으나 유의적인 차이는 없었다 $(P>$ 0.05). Vaccenic acid는 $\mathrm{T} 3$ 처리구가 $\mathrm{T} 2$ 처리구 와 비교하여 유의적으로 높게 나타났으며, Oleic acid는 T2 처리구가 $\mathrm{T} 1$ 처리구와 비교하 여 유의적으로 높게 나타났다 $(P<0.05)$. Total MUFA, total PUFA 및 total UFA/SFA는 처리구 간에 유의적인 차이가 없었다 $(P>0.05)$.

Oleic acid는 단일 불포화지방산으로서 다량 섭취 시 혈중 중성지방이나 콜레스테롤의 감소 를 가져오므로 동맥경화증과 같은 성인병에 유 익한 효과가 있다고 보고하였으며 (Grundy, 1986), Vaccenic acid는 주로 우유와 젖소 및 기타 반 추동물의 근육 지방에서 발견되는 지방산으로 서, 천연 항암물질인 conjugated linoleic acid (CLA)로 대사되는 전구물질로 알려져 있다 (Griinari 등, 2000).

본 시험의 결과 잣 부산물의 급여는 일반적 인 잣의 함량이 낮기 때문에 잣에 함유된 지방 산 중 가장 풍부한 지방산인 Linoleic acid의 함 량 증가가 나타나지 않았으나, 유익한 지방산 인 Oleic acid 및 Vaccenic acid에는 긍정적인 영향을 미치는 것으로 사료된다.

\section{6. 분내 유해가스 발생 물질의 함량}

비육돈에 있어서 잣 부산물의 급여에 따른 분내 유해가스 물질의 함량은 Table 8에 나타
내었다. 암모니아, 황화수소 및 휘발성 지방산 중 Acetic acid 함량에 있어서는 처리구간에 유 의적인 차이가 없었다 $(P>0.05)$.

고 등(2006)은 잣송이 부산물을 이용하여 퇴 비화 과정 시 발생하는 유해가스 발생 물질의 함량을 측정한 결과, 잣송이 부산물을 이용한 처리구에서 황화수소 및 암모니아의 발생 농도 가 톱밥만을 사용하는 처리구보다 낮았다고 보 고하였다.

\section{IV. 요 약}

본 연구는 잣 부산물의 급여가 비육돈의 생 산성, 혈액성상, 도체특성 및 분내 악취 발생물 질에 미치는 영향에 대해 알아보기 위하여 시 험을 실시하였다. 3원 교잡종 비육돈 60 두를 공시하였으며, 시험 개시시 체중이 $86.01 \pm 0.25$ $\mathrm{kg}$ 이었고, 35 일간 사양시험을 실시하였다. 시 험설계는 1) T1(미루나무톱밥 2\%), 2) T2(미루 나무톱밥 $1 \%$ +잣 부산물 $1 \%$ ) 및 3) $\mathrm{T} 3$ (잣 부 산물 $2 \%$ )로 3 개 처리를 하여 처리당 5 반복, 반 복당 4두씩 완전임의 배치하였다. 사양시험 기 간 동안 일당증체량, 일당사료섭취량 및 사료 효율은 처리구간에 유의적인 차이가 없었다 $(P>0.05)$. 또한, 영양소 소화율 및 혈액특성은 처리구간에 유의적인 차이가 없었다 $(P>0.05)$. 육색에 있어서 적색도를 나타내는 $\mathrm{a}$-값 및 육 의 관능평가 결과 육색은 $\mathrm{T} 3$ 처리구가 $\mathrm{T} 1$ 처리 구와 비교하여 유의적으로 높게 나타났다 $(P<$ $0.05)$. 살코기 내 지방산 조성에 있어서 $\mathrm{C} 18: 1$ 및 total MUFA는 $\mathrm{T} 1$ 처리구가 다른 처리구와 비교하여 유의적으로 가장 낮게 나타났으나 
$(P<0.05), \omega 6$ 및 total PUFA는 T1 처리구가 $\mathrm{T} 2$ 처리구와 비교하여 유의적으로 높은 함량을 나 타내었다 $(P<0.05)$. 지방 내 지방산 조성에서 있 어서 total SFA는 $\mathrm{T} 2$ 처리구가 $\mathrm{T} 3$ 처리구와 비 교하여 유의적으로 높게 나타났으며 $(P<0.05)$, $\mathrm{C} 18: 1$ 는 $\mathrm{T} 2$ 처리구가 $\mathrm{T} 1$ 처리구보다 높은 함량 을 나타내었다 $(P<0.05)$. 분내 유해가스 발생 물 질의 함량에 있어서는 처리구간에 유의적인 차 이가 없었다 $(P>0.05)$. 결론적으로, 본 시험의 결과 비육돈에 잣 부산물의 급여는 육색 및 지 방산 조성에 영향을 미치는 것으로 사료된다.

\section{$\mathrm{V}$. 인 용 문 헌}

1. Alder, H. E. and Damassa, A. J. 1980. Effect of ingested Lactobacilli on Salmonella infantis and Escherichia coli and on intestial flora, pasted vents and chick growth. Avian Disease 24:868.

2. Allain, C. C., Poon, L. S., Chan, C. S. G., Richmond, W. and Fu, P. C. 1974. Enzymatic determination of total serum cholesterol. Clin Chem. 20:470-475.

3. AOAC. 1995. Official method of analysis. 16th ed. Association of official Analytical Chemists. Washington, D. C.

4. Baricevic, D., Milevoj, L. and Borstnik, J. B. 2001. Insecticidal effect of oregano Origanum vulgare L. ssp. hirtum Inter. J. Horticult. Sci. 7: 84-88.

5. Barrow, P. A. 1992. Probiotics for chickens. In R. Fuller (Ed.). Probiotics: The Scientific basis. Chapman \& Hall, London.

6. Cimanga, K., Kambu, K., Tona, L., Apers, S., De Bruyne, T., Hermans, N., Totte, J., Pieters, L. and Vlietinck, A. J. 2002. Correlation between chemical cornposition and antibacterial activity of essential oils of some aromatic medicinal plants growing in the Democratic Republic of Congo. J. Ethnopharmacol. 79:213-220.

7. Critchfield, W. B. and Little, E. L. Jr. 1966. Geographic distribution of the pines of the world. US Dept. Agri., Forest Serv. Micellaneous Publ.
No. 991.

8. Duncan, D. B. 1955. Multiple range and multiple F tests. Biometrics. 11:1-14.

9. Folch, J., Lees, M. and Sloane-Stanley, G. H. 1957. A simple method for the isolation and purification of total lipid from animal tissues. J. Biol. Chem. 226:497-509.

10. Griinari, J. M., Corts, B. A., Lacy, S. H., Chouinard, P. Y., Nuemela, K. V. V. and Bauman, D. E. 2000. Conjugated linoleic acid is synthesized endogenously in lactating dairy cows by delta-9 desaturase. J. Nutr. 130:2285-2291.

11. Grundy, S. M. 1986. Comparison of monounsaturated fally acids and carbohydrates for loweing plasma cholesterol. National England Journal of Medicine. 314:735-751.

12. Hofmann, K., Hamm R. and Bluchel, E. 1982. New information on the determination of water binding in meat by the filter paper press method. Fleischwirtsch 62:87-94.

13. Kim, Y. K., Chung, K. N., Hirosh Ishi and Shigeru Muraki. 1986. Volatile components of pinenut. Korean J. Food Sci. Technol. 18(2):105109.

14. Naoyuki, N. and Yoshiharu, F. 1995. The elevation of plasma concentration of high-density lipoprotein cholesterol in mice fed with protein from proso millet. Biosci. Biotech. Biochem. 59, 333-335.

15. NRC. 1998. Nutrient Requirements of swine. National Research Council, Academy Press.

16. SAS. 1996. SAS user's guide: Statisics, SAS Inst, Inc., Cary, NC.

17. Witte, V. C., Krause, G. F. and Bailey, M. E. 1970. A new extraction method for determining 2thiobarbituric acid values for pork and beef during storage. J. Food Sci. 35:582-587.

18. 고용균, 신종서, 김창혁, 홍병주, 박재인, 라창식. 2006. 잣송이를 이용한 축사환경개선제 및 사료 첨가제 개발에 관한 연구보고서. 강원대학교. 농 림부.

19. 곽완섭, 윤정식. 2003. 농산업부산물들에 대한 배 
출 현장 조사 및 사료적 가치 평가. 한국동물자 원과학회지. 45(2):251-264.

20. 권오석, 김인호, 김지훈, 홍종욱, 민병준, 이원백, 손경승. 2003. 비육돈에 있어서 생약제 혼합물의 급여가 성장률, 영양소 소화율, 혈청학적 변화 및 도체특성에 미치는 영향. 한국산학기술학회. 4(4):334-340.

21. 권오석, 유종상, 민병준, 손경승, 조진호, 김해진, 진영걸, 김인호. 2005. 사료내 약용식물(인진쑥, 오가피 및 마늘)의 첨가가 포유돈, 포유자돈 및 이유자돈의 성적 및 혈청특성에 미치는 효과. 한 국동물자원학회지. 47:501-512.

22. 길용현. 2007. 잣송이 부산물 첨가급여가 브로일 러와 육성돈의 생산성에 미치는 영향. 강원대학 교 석사학위논문.

23. 김 명, 이숙희, 최홍식. 1984. 잣지질 성분의 분 획정량 및 각 획분의 지방산 조성. 한국영양식품 학회지. 13(4):406-412.

24. 농림부. 2005. 산림청 임업통계연보. 제 35호, pp. 288.

25. 농림부. 2006. 산림청 임업통계연보. 제 36호, pp. 296.

26. 박영서, 정명수. 2005. 잣 성분의 형중 콜레스테 롤 저하효과. 한국식품과학회지. 37(5):702-708.

27. 안종호, 김영직. 2003. 쑥 분말의 급여가 돈육의 이화학적 특성에 미치는 영향. 한국축산식품학회
지. 23(1):16-20.

28. 양재경, 강병국, 김태홍, 홍성철, 서원택, 최명석. 2002. 침엽수 잎으로부터 효율적인 정유추출법 탐색 및 정유성분 분석. 한국생물공학회지. 17 (4):357-364.

29. 임용숙, 박경남, 백만종, 이신호. 2001. 병원성 미 생물에 대한 소나무 추출물의 향균효과. $\mathrm{K}$ growth Avian Disease. 24:868.

30. 주선태, 허선일, 이정일, 이제룡, 김동훈, 하영래, 박구부. 1999. 양파 부산물 급여가 돈육의 지질 산화와 혈액성상 및 항돌연변이성에 미치는 영 향. 한국동물자원과학회지. 41:671-678.

31. 최호성, 박재홍. 2007. 유기 육계에 침엽수 부산 물과 추출물의 급여가 성장, 장기 및 맹장내 미 생물에 미치는 영향. 한국가금학회지. 34(1):1521.

32. 홍원택, 고경민, 이재곤, 장희진, 곽재진. 2002. 소나무 잎 추출물의 휘발성 성분, Journal of Korea Society of Tabacco Science. 24(1):53-59.

33. 홍종욱, 김인호, 김지훈, 권오석, 이상환, 서완수, 김 철, 김을상, 정윤화. 2002. 비육돈에 있어 황 기, 인삼, 양파 혼합물의 급여가 성장 및 도체특 성에 미치는 영향. 한국식품영양과학회지. 31 : 149-154.

(접수일자 : 2007. 10. 1. / 채택일자 : 2007. 12. 5.) 